\title{
Korozja i metody zabezpieczeń antykorozyjnych w konstrukcjach okrętowych
}

\section{Corrosion and methods for corrosion protection in marine structures}

\section{Streszczenie}

Korozja jako zjawisko powoduje za sobą olbrzymie straty i generuje dużo problemów dla technologów, konstruktorów i spawalników. Zjawisko to jest trudne do zminimalizowania - wręcz niemożliwe do uniknięcia. Opracowano dużo metod zabezpieczeń konstrukcji przez korozją, a wybór właściwej musi być oparty na odpowiedniej wiedzy nt. warunków pracy i wymagań stawianych konstrukcji. W artykule przedstawiono rodzaje korozji konstrukcji okrętowych, główne miejsca jej występowania, wymagania stawiane zabezpieczeniom antykorozyjnym, przygotowanie konstrukcji do malowania i podstawowe metody zabezpieczeń antykorozyjnych.

\section{Wstęp}

Korozja jest destrukcją materiału w wyniku jego reakcji z otoczeniem. Spośród wszystkich procesów niszczenia korozja powoduje największe straty finansowe. Szacowane straty w $2010 \mathrm{r}$. na jedną osobę wynosiły ok. 1000 $\div 1500 \$[8]$. W Polsce w tym okresie straty korozyjne wynosiły $8 \%$ PKB, tj. 100 mld zł [2].

Pod względem korozji konstrukcje okrętowe pracują w trudnych warunkach (rys. 1). Wynurzoną część okrętu oraz jego wnętrze (zbiorniki balastowe, ładownie ze wszystkimi elementami wyposażeniowymi i urządzeniami) atakuje wilgotne i zasolone powietrze morskie. Część podwodna kadłuba jest zanurzona w słonej wodzie, a więc $w$ elektrolicie o wysokim przewodnictwie elektrycznym - powstają wtedy sprzyjające warunki dla przebiegu korozji elektrochemicznej.

Czyszczenie i konserwacja konstrukcji kadłubowych mają na celu zabezpieczenie przed

Mgr inż. Michał Szymczak - Baltramp Shipping. szkodliwym wpływem korozji, a także zapewnienie estetycznego wyglądu oraz poprawienie charakterystyk oporowych, np. przez likwidowanie skutków porastania kadłuba. Stosowanie powłok oraz różnych metod, które ten proces hamują, jest wymaganiem dotyczączym prawidłowej eksploatacji statku. Na rysunku 1 pokazano, jak agresywne jest środowisko morskie, które powoduje, że nawet najlepsze farby i zabezpieczenia nie mogą w pełni uchronić przed jego działaniem. Odpowiednie przygotowanie konstrukcji i konserwacja powłokami malarskimi w znacznym stopniu zmniejszają i spowalniają efekty korozyjne oraz zapewniają zabezpieczenie nawet na kilka lat.
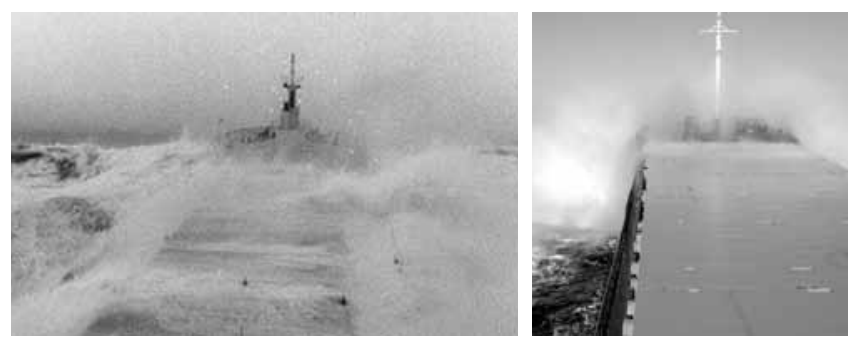

Rys. 1. Typowe warunki na morzu [9]

Fig. 1. Typical weather conditions at sea [9] 


\section{Główne rodzaje korozji konstrukcji okrętowych}

Pod względem rodzaju zniszczenia korozyjnego można rozróżnić korozję ogólną - rozprzestrzenioną na całej powierzchni, w sposób równomierny lub nierównomierny i korozję miejscową - zniszczenia korozyjne zlokalizowane są jedynie w pewnych miejscach powierzchni, podczas gdy pozostała część pozostaje niezmieniona (rys. 2). wej:

Wyróżnia się następujące rodzaje korozji miejsco-

- korozja plamkowa - zniszczenie metalu zajmuje stosunkowo duże części powierzchni i nie sięga zbyt głęboko,

- korozja wżerowa - niszczenie metalu lokalizuje się na niedużych obszarach powierzchni, a głębokość lokalnego ubytku korozyjnego jest kilkakrotnie większa od na pozostałej powierzchni,

- korozja punktowa - niszczenie metalu odbywa się na bardzo małej powierzchni (średnica powierzchni zaatakowanej wynosi od 0,2 do $1,0 \mathrm{~mm}$ ), a zniszczenie jest bardzo głębokie, aż do przebicia elementu metalowego na wylot,

- korozja międzykrystaliczna - powoduje selektywne niszczenie metalu na granicy ziarn, przy niewielkiej zmianie wyglądu zewnętrznego metalu (następuje poważne zwiększenie kruchości metalu),

- pęknięcia korozyjne - występują wskutek równoczesnego działania naprężeń rozciągających i środowiska korozyjnego,

- korozja selektywna - niszczeniu ulega tylko jeden ze składników stopu,

- korozja podpowierzchniowa - rozpoczyna się na powierzchni i rozprzestrzenia głównie pod powierzchnią, powodując tworzenie pęcherzy na powierzchni metalu lub jego rozwarstwianie [1, 4].

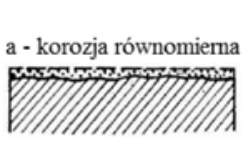

KOROZJA OGÓLNA

$\mathrm{b}-\mathrm{k}$. nierównomierna $\quad \mathrm{c}-\mathrm{k}$. strukturalno-selektywna
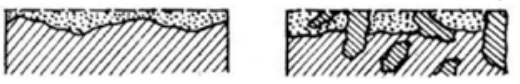

KOROZJA MIEJSCOWA
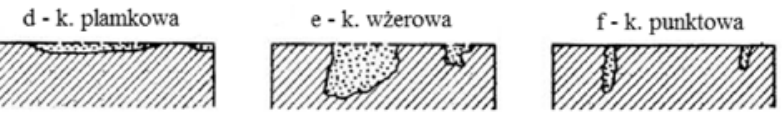

$\mathrm{g}-\mathrm{k}$. miedzykrystaliczn

h - k. sródkrystaliczna

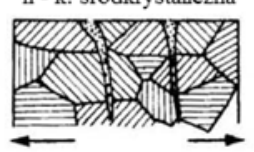

$\mathrm{i}-\mathrm{k}$. podpowierzchniowa
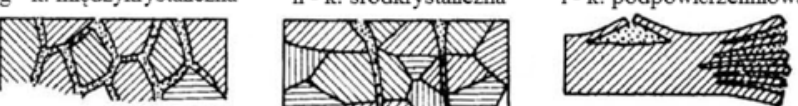

Rys. 2. Rodzaje uszkodzeń korozyjnych [4]

Fig. 2. Types of corrosion damage [4]

\section{Korozja atmosferyczna [1, 4]}

Podstawowym czynnikiem decydującym o szybkości korozji atmosferycznej $i$ jej mechanizmie jest wilgotność powietrza, a tym samym stopień nawilgocenia metalu, tj. grubość warstwy wilgoci na powierzchni metalu. Wyróżnić można trzy typy:

- mokrą, na powierzchni metalu gdyby występuje kroplowa kondensacja wilgoci, tworząca warstewkę widoczną gołym okiem (oddziaływania deszczu, bryzgów wody),

- wilgotna, gdy na powierzchni metalu występuje bardzo cienka i niedostrzegalna warstewka wilgoci,

- suchą, w której nie ma warstwy wilgoci na powierzchni metalu.

Ze względu na zmienność warunków konstrukcje okrętowe podlegają wszystkim wymienionym typom korozji. W powietrzu morskim znajdują się rozpylone chlorki i zanieczyszczenia gazami spalinowymi - gazowe związki siarki, co potęguje zjawisko korozji.

\section{Korozja w wodzie morskiej $[1,4]$}

Aktywność korozyjna wody morskiej zależy od stopnia jej zasolenia, składu chemicznego i temperatury. Skład chemiczny wody w morzach otwartych jest prawie niezmienny, natomiast w morzach śródlądowych ulega znacznym wahaniom (tabl. I).

Duża zawartość jonów chlorkowych powoduje wysoką aktywność korozyjną wody morskiej w stosunku do żelaza i innych metali. Szybkość korozji blachy stalowej, zanurzonej w wodzie morskiej, wynosi ok. 0,1 mm/rok.

Porastanie kadłuba statku ma znaczny wpływ na procesy korozyjne, ponieważ powodują:

- bardziej zlokalizowane punkty korozyjne,

- zmiany składu chemicznego wody w wyniku wydzielania tlenu przez porosty roślinne, zakwaszenia wody przez dwutlenek węgla wydzielany przez organizmy zwierzęce oraz tworzenia siarkowodoru w wyniku rozkładu martwych organizmów,

- uszkodzenia powłok ochronnych przez niektóre organizmy porastające,

- uszkodzenia powłok ochronnych przez organizmy odznaczające się większą przyczepnością do powłok ochronnych niż do powłok do podłoża, co w wypadku obciążeń mechanicznych powoduje odrywanie się porostów razem z powłoką.

Tablica I. Ogólny stopień zasolenia wód

Table I. The overall level of salinity

\begin{tabular}{|c|c|}
\hline Zbiornik wodny & Ogólny stopień zasolenia, \% \\
\hline Ocean Atlantycki & 3,54 \\
Ocean Spokojny & 3,49 \\
Morze Śródziemne & $3,7-3,9$ \\
Morze Czerwone & do 4,1 \\
Morze Bałtyckie (Zatoka Botnicka) & $0,2-0,5$ \\
Morze Bałtyckie (część południowa) & $0,7-1,0$ \\
Zwykła woda rzeczna & $0,01-0,03$ \\
\hline
\end{tabular}




\section{Wpływ przepływu wody morskiej $[1,6]$}

Wzrost prędkości przepływu wody morskiej przyczynia się do lepszego mieszania się wody, a tym samym ułatwia dopływ tlenu do ogniw korozyjnych. Dzięki temu im większa jest prędkość wody, tym większa będzie szybkość korozji i bardziej równomierne ubytki na korodującej powierzchni metalu. Przy większej prędkości wody następuje zjawisko erozji korozyjnej występujące przede wszystkim w pobliżu śrub napędowych (rejon tylnicy). W tym miejscu występuje często kawitacja korozyjna, która polega na niszczeniu mechanicznym warstewek ochronnych, a przede wszystkim bezpośrednio struktury samego metalu - może to powodować olbrzymią szybkość niszczenia metalu (50 $\mathrm{mm} /$ rok i więcej). W przypadku uszkodzenia powłoki ochronnej metal ulega szybkiej korozji wżerowej. Dlatego miejsca takie powinny być szczególnie starannie chronione powłokami malarskimi. Na rysunku 3a przedstawiono oczyszczoną i przygotowaną do malowania tylnicę statku, a na rysunku $3 \mathrm{~b}$ proces nanoszenia powłok malarskich.

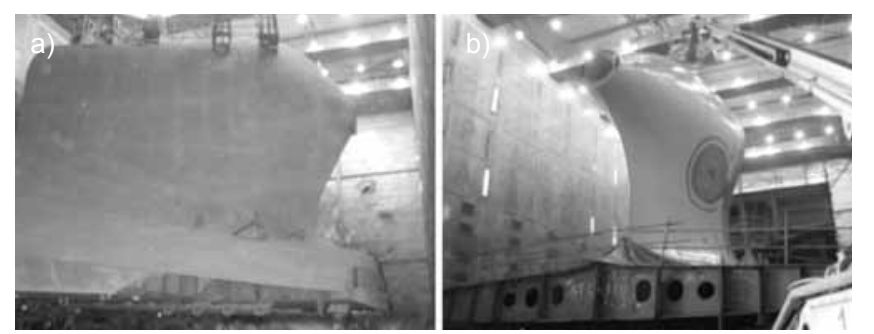

Rys. 3. Przygotowanie (a) i malowanie (b) tylnicy statku [9]

Fig. 3. The process of surface preparation (a) and painting (b) of stern [9]

\section{Wpływ głębokości zanurzenia w wodzie morskiej [6]}

Największą szybkość korozji konstrukcji zanurzonej w wodzie morskiej obserwuje się tuż ponad powierzchnią, wskutek kapilarnego podnoszenia wody. Jest to obszar najczęstszego zwilżania konstrukcji przez bryzgi i falowanie. Szybkość korozji poniżej powierzchni wody szybko maleje, a na głębokości $2 \mathrm{~m}$ jest niewiele większa niż na większych głębokościach.

\section{Uszkodzenia korozyjne kadłubów okrętowych $[1,6]$}

Ubytki korozyjne pociągają za sobą wysokie koszty powstające z konieczności:

- zwiększenia grubości elementów konstrukcyjnych w nowych statkach ponad wartości wymagane względami wytrzymałościowymi, co powoduje zmniejszenie nośności statku,

- odnowienia/wymiany elementów konstrukcyjnych o przekroczonych dopuszczalnych wartościach grubości na statkach już eksploatowanych.

Korozja równomierna nie stanowi jednak dużego zagrożenia dla konstrukcji okrętowych. Najbardziej niebezpieczna jest korozja wżerowa. Wszelkie środki zabezpieczające kadłub przed korozją należy chronić. W niektórych wypadkach głębokość wżerów powstających w ciągu jednego roku może dochodzić do $5 \mathrm{~mm}$. Warunki powstawania korozji od strony zewnętrznej kadłubów statków różnych typów są podobne. Od strony wewnętrznej najintensywniejszej korozji podlegają zbiornikowce.

\section{Korozja konstrukcji wewnętrznej [6]}

Korozja najszybciej występuje pod kotłami wskutek działania wody, ciepła i popiołu, a dalej w zęzach, w zbiornikach głębokich, w zbiornikach dna podwójnego (szczególnie w zbiornikach balastowych - rys. 4), w skrajnikach i skrzyniach łańcuchowych. Poza tymi elementami szybka korozja postępuje w miejscach niedostępnych dla przeglądu, jak np. pokłady stalowe pod drewnianym poszyciem albo szalowane poszycie burt.

Maszty i rurociągi podlegają intensywnej korozji w miejscach, gdzie gromadzi się brud i wilgoć oraz gdzie konserwacja jest utrudniona. Wewnętrzna korozja rurociągów stanowi również poważny problem stąd próby zabezpieczania ich wewnątrz i na zewnątrz.

Najsilniejszej korozji w owrężeniu poprzecznym podlegają wręgi $w$ bezpośrednim sąsiedztwie połączeń z węzłówkami obłowymi i pokładowymi oraz wzdłużnikami burtowymi, w miejscach wskazanych (rys. 4) gromadzi się brud i pył łatwo wchłaniający wilgoć,

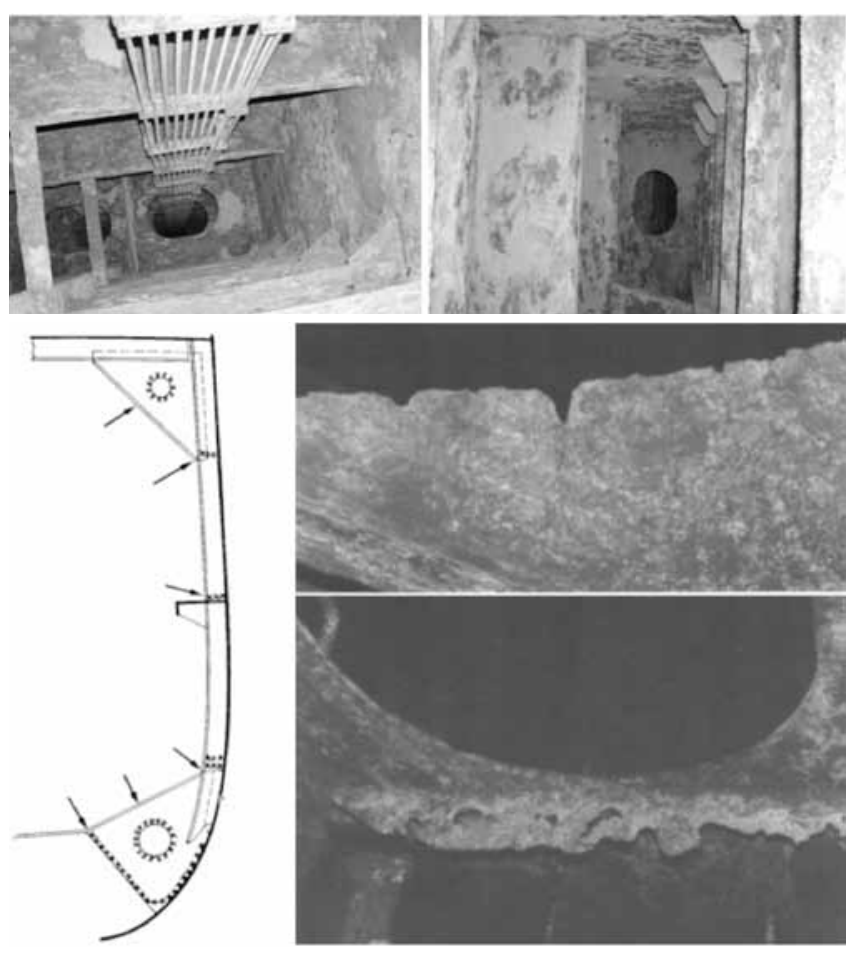

Rys. 4. Miejsca szczególnie podatne na korozję (przekrój poprzeczny), zbiornik balastowy („korozja nożowa”) i zbiornik balastowy $z$ instalacją - rozległa korozja $[5,9]$

Fig. 4. Places particularly susceptible to corrosion (cross-section), ballast tank (knife-line attack) and ballast tank installation - extensive corrosion $[5,9]$ 
zawierający ponadto składniki chemiczne, które przyspieszają korozję. Korozja wręgów jest szczególnie szybka w zbiornikach wodnych i ropowych, burtowych i skrajnych. Wzdłużniki burtowe korodują szybciej od strony wierzchniej (rys. 5). Jeśli wzdłużniki burtowe składają się z kilku elementów, korozja może rozsadzić ich wiązania.

Nie wolno dopuścić do nadmiernego osłabienia denników pod grodziami wodoszczelnymi i wręgami ramowymi (rys. 6). Najsilniejsza korozja grodzi poprzecznych występuje w zęzach oraz na dolnych pasach poszycia i węzłówkach.

Poszycie dna wewnętrznego ulega silnej korozji z obu stron. Od wierzchniej strony nasilenie korozji występuje w zęzach, skrzyniach ściekowych, tzn. wszędzie, gdzie przez dłuższy czas może zalegać woda ściekowa i brud. Szybkość korozji dna wewnętrznego w ładowniach zależy też od rodzaju przewożonego ładunku. Szczególnie niekorzystny wpływ wywierają węgiel, sól, ziarno i różne produkty
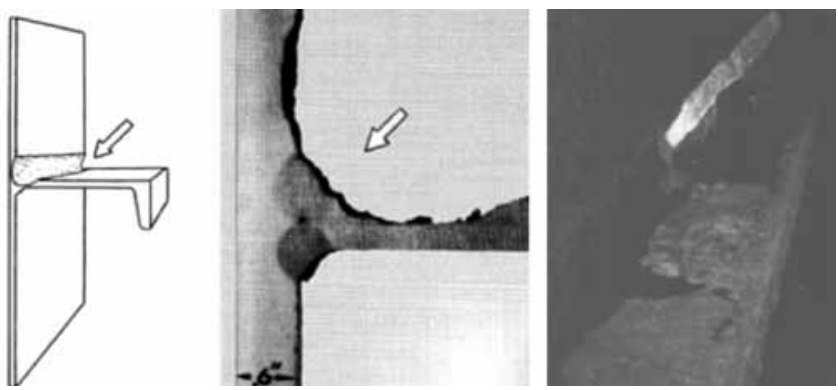

Rys. 5. Korozja usztywnienia wzdłużnego, obszar spoiny - wzdłużnik burtowy $[4,9]$

Fig. 5. Corrosion of longitudinal reinforcement, weld region - stringer boards $[4,9]$

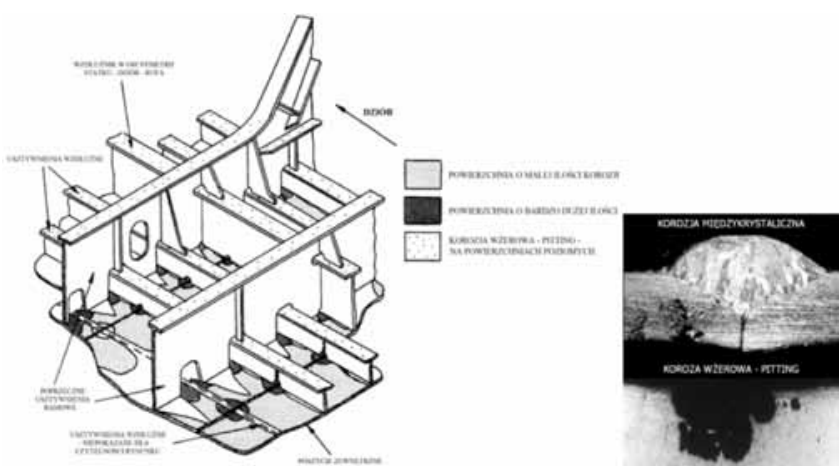

Rys. 6. Konstrukcja dna zbiornikowca - zbiornik denny [5]

Fig. 6. Tanker bottom design - the tank bottom [5]

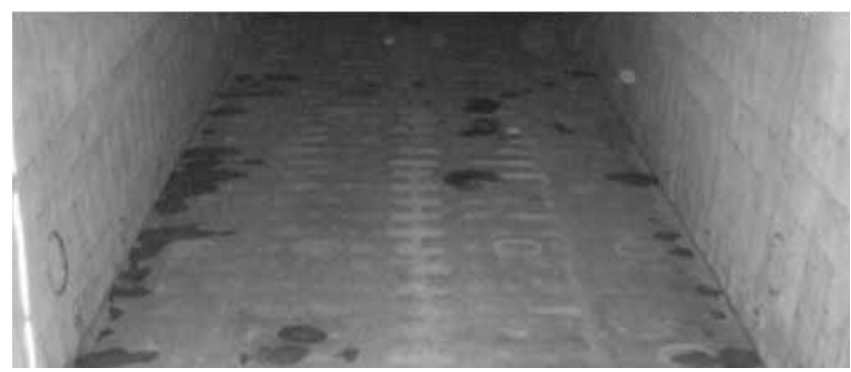

Rys. 7. Ładownia drobnicowca uniwersalnego przed czyszczeniem i konserwacją [9]

Fig. 7. Universal general cargo hold before cleaning and maintenance [9] chemiczne. Dno wewnętrzne w pobliżu luków ładunkowych koroduje bardzo szybko wskutek nawilgacania podłogi (rys. 7).

\section{Korozja konstrukcji zewnętrznej $[1,6]$}

Najszybciej korozji ulega poszycie zewnętrzne części podwodnej, a ze względu na znacznie trudniejszą konserwację tego miejscu. Dostęp do poszycia zewnętrznego możliwy jest średnio co 2,5 roku w czasie dokowania [3]. Korozja poszycia zewnętrznego następuje na ogół w formie korozji wżerowej, miejscowej lub ogólnej. Powierzchnia części podwodnej kadłuba narażona jest na uszkodzenia mechaniczne spowodowane przez osiadanie statku na zalegających przedmiotach podczas odpływów w portach, otarć na mieliznach lub pływania w lodach. W miejscach uszkodzenia farby mogą powstać głębokie wżery (rys. 8).

Poszycie zewnętrzne kadłuba najsilniej koroduje między wodnicą największego a najmniejszego zanurzenia. Stal pokryta roztworem soli, będąc pod wpływem działania światła i ciepła, w obecności tlenu z powietrza silnie koroduje. Roztwór soli dostaje się przez powłokę ochronną farby i po pewnym czasie przedostaje się przez nią do powierzchni stali.

Pokłady podlegają silnej korozji pod wpływem bryzgów wody morskiej, która wysychając, pozostawia osad soli. Szczególnie szybko postępuje korozja przy nagrzewaniu się pokładu pod wpływem działania promieni słonecznych. Poważna korozja nadbudówek pojawia się stosunkowo rzadko, ponieważ ze względów estetycznych maluje się je zazwyczaj często - szczególnie na statkach pasażerskich.

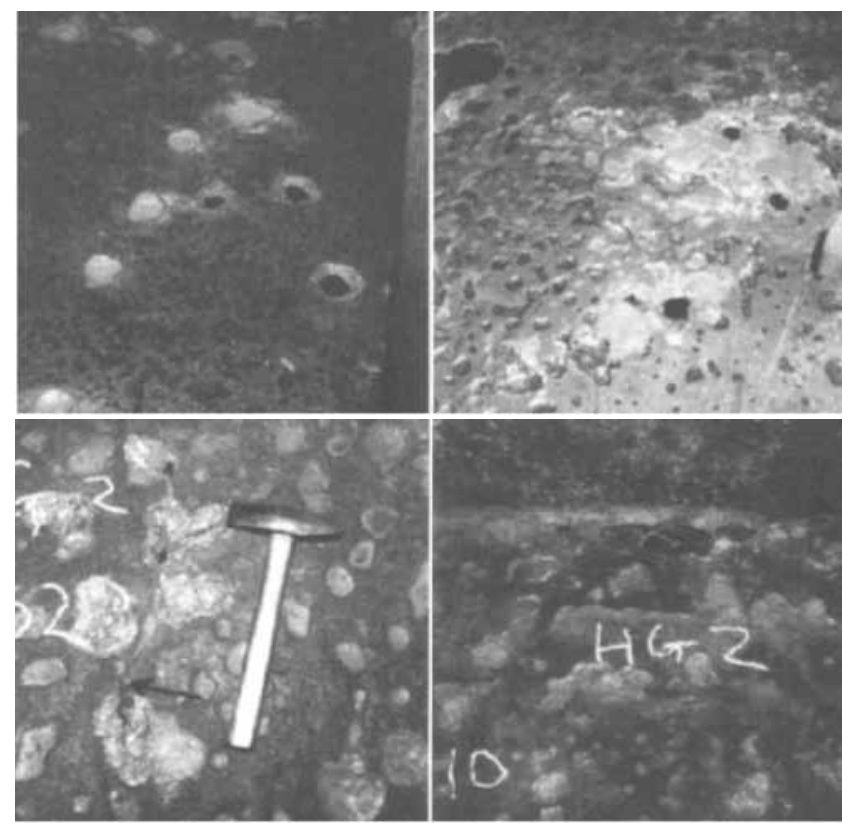

Rys. 8. Korozja wżerowa poszycia zewnętrznego [9]

Fig. 8. Outer shell pitting [9] 


\section{Sposoby ograniczenia zjawiska korozji $[1,4,6]$}

\section{Czyszczenie konstrukcji}

Warunkiem trwałości powłoki malarskiej jest jej ścisłe przyleganie do podłoża, stąd konieczność odpowiedniego przygotowania powierzchni przed malowaniem. W celu ujednolicenia wymagań dotyczących czystości powierzchni przeznaczonych pod powłoki malarskie w przemyśle okrętowym wprowadzono klasyfikację przedstawioną w tablicy II.

Przyjęto następujące klasy czystości konstrukcji (rys. 9 i 10):

- Sa 1 - zgrubne oczyszczenie strumieniowo-ścierne: usunięcie słabo przylegającej rdzy, zgorzeliny, starej powłoki malarskiej i obcych zanieczyszczeń (np. soli rozpuszczalnych w wodzie). Możliwe jest pozostawienie starej powłoki malarskiej dobrze przyczepnej do podłoża;

- Sa 2 - gruntowne oczyszczenie strumieniowościerne: usunięcie starej powłoki malarskiej, rdzy, zgorzeliny. Powierzchnia szara, metaliczna. Szczątkowe zanieczyszczenia przylegają do podłoża;

- Sa 2.5 - bardziej gruntowne oczyszczenie strumieniowo-ścierne: całkowite usunięcie zgorzeliny, rdzy, starej powłoki malarskiej. Dopuszczalne ściemnienia i przebarwienia szczególnie w miejscach silnego uszkodzenia korozyjnego. Ślady zanieczyszczeń w kształcie kropel lub pasków;

- Sa 3 - oczyszczenie strumieniowo-ścierne: do stali wzrokowo czystej. Jednolicie metaliczna barwa. Całkowite usunięcie zgorzeliny, rdzy, starej powłoki i innych zanieczyszczeń;

- St 2 - oczyszczenie ręczne - powierzchnia została starannie oczyszczona szpachelkami, skrobakami, szczotkami stalowymi; wykazuje metaliczny połysk.

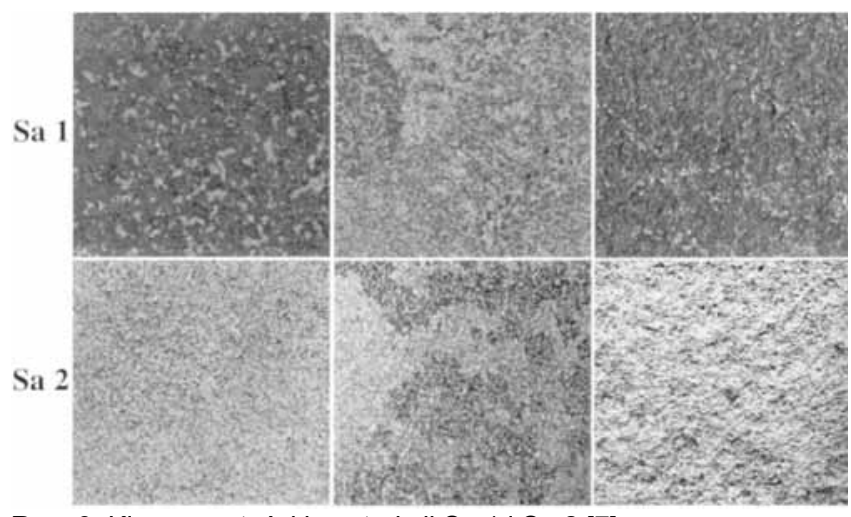

Rys. 9. Klasy czystości konstrukcji Sa 1 i Sa 2 [7]

Fig. 9. Sa 1 and Sa 2 cleanliness class for structure [7]

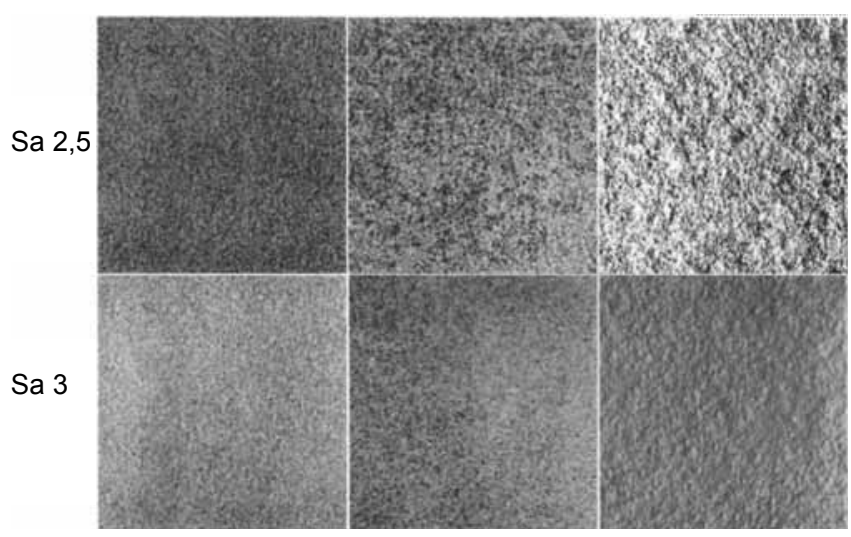

Rys. 10. Klasy czystości konstrukcji Sa 2,5 i Sa 3 [7]

Fig. 10. Sa 2.5 and Sa 3 cleanliness class for structure [7]

- St 3 - oczyszczenie ręczne - powierzchnia została szczególnie starannie oczyszczona szpachelkami, skrobakami, szczotkami stalowymi (oczyszczanie w kierunkach krzyżujących się). Powierzchnia wykazuje zdecydowanie metaliczny połysk [6, 7].

Tablica II. Dopuszczalne niezgodności powierzchni przygotowanej do malowania

Table II. Acceptable defects in the surface prepared for painting

\begin{tabular}{|l|l|l|}
\hline \multirow{2}{*}{ Rodzaj niezgodności } & \multicolumn{2}{c|}{ Wg ISO 8501-3 dla agresywności korozyjnej środowiska } \\
\cline { 2 - 3 } & \multicolumn{1}{c|}{ niska P1 } & \multicolumn{1}{c|}{ wysoka P2 } \\
\hline Odpryski spawalnicze & $\begin{array}{l}\text { powierzchnia wolna od odprysków słabo } \\
\text { przylegających }\end{array}$ & nie dopuszcza się \\
\hline Nierówności lica spoiny & powinny być usunięte ostre nierówności & nie dopuszcza się \\
\hline Żużle spawalnicze & nie dopuszcza się & nie dopuszcza się \\
\hline Podtopienia & mogą występować & powierzchnia gładka \\
\hline Porowatość spoin & dopuszcza się & nie dopuszcza się \\
\hline Zakończenia spoiny spawalniczej & mogą występować & powinny być usunięte ostre nierówności \\
\hline $\begin{array}{l}\text { Kratery i wgniecenia o szerokości większej od } \\
\text { głębokości }\end{array}$ & powinny być usunięte ostre nierówności & nie dopuszcza się \\
\hline Wżery - szerokość mniejsza od głębokości & powinny być usunięte ostre nierówności & nie dopuszcza się \\
\hline Zawalcowania, wtrącenia obce & powierzchnia wolna od tych niezgodności & $\begin{array}{l}\text { powierzchnia wolna od tych niezgodności } \\
\text { i gładka }\end{array}$ \\
\hline Ostre, wolne krawędzie po cięciu & gładkie krawędzie & $\begin{array}{l}\text { nie dopuszcza się - stępić, zaokrąglić } \\
\text { przez szlifowanie }\end{array}$ \\
\hline
\end{tabular}




\section{Metody przygotowania powierzchni $[3,6]$}

Procesy przygotowania powierzchni pod powłokę ochronną można podzielić na: czyszczenie wstępne i czyszczenie właściwe. Operacje te znacznie różnią się dla konstrukcji nowych i eksploatowanych (rys. 11).

Kryteria doboru sposobu oczyszczania powierzchni zależą od wielkości i kształtu powierzchni, rodzaju metalu, agresywności środowiska pracy i charakteru zanieczyszczeń.

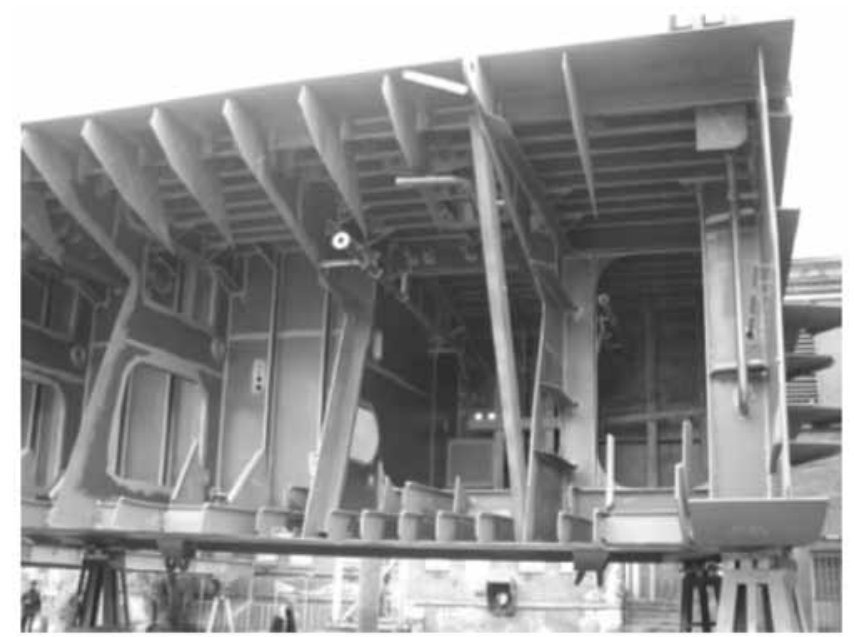

Rys. 11. Konstrukcja zabezpieczona przed korozją [9]

Fig. 11. Design protected by bottom paint [9]

Metody mechaniczne: ręczne czyszczenie, tzn. skrobanie, młotkowanie, szczotkowanie, szlifowanie. W celu zwiększenia wydajności można stosować specjalne narzędzia pneumatyczne lub elektryczne. Metody te stosowane są podczas przygotowania kadłuba do nałożenia powłoki malarskiej oraz remontów. Wadą tej metody jest duża pracochłonność, możliwość kaleczenia blach i niedostateczne przygotowanie powierzchni pod powłokę malarską. Obecnie częściej usuwa się zgorzelinę za pomocą materiału ściernego. W zależności od rodzaju ścierniwa stosuje się: piaskowanie, śrutowanie oraz mycie wodą pod wysokim ciśnieniem (tabl. III). Zalety piaskowania to duża wydajność procesu i możliwość zupełnego usunięcia zgorzeliny. Wady to powstawanie dużej ilości pyłu szkodliwego dla zdrowia i konieczność odpowiedniej ochrony pracowników zatrudnionych przy tym procesie.
Metody fizykochemiczne: odtłuszczanie rozpuszczalnikowe, mycie alkaliczne, kwaśne, parowo-wodne oraz wytrawianie, które polega na odtłuszczeniu blach, wytrawieniu w roztworze kwasu, płukaniu i malowaniu ochronnym.

Metody cieplne: Metoda usuwania zgorzeliny i rdzy za pomocą płomienia polegającą na wykorzystaniu różnic współczynników rozszerzalności cieplnej zgorzeliny i stali. Do czyszczenia płomieniem stosuje się specjalne palniki wielodyszowe. Pod wpływem działania płomienia i nagłego skoku temperatury na powierzchni oczyszczanej warstwa zgorzeliny i rdzy kruszy się i odskakuje - pozostaje na powierzchni oczyszczonej w postaci luźnego osadu, dającego się łatwo usunąc szczotką stalową. Po oczyszczeniu powierzchnia stali jest czysta, sucha i ogrzana. Zaletą jest pokrywanie farbą ciepłej powierzchni, gdyż uzyskujemy wtedy bardzo dobrą i szczelną powłokę.

Czyszczenie chemiczne zbiorników ładunkowych: Najpierw zbiornik jest czyszczony i natryskowo odtłuszczany środkami emulgującymi na wszystkich powierzchniach, następnie płukany wodą słodką. Aby usunąć rdzę, natryskuje się parokrotnie powierzchnię zbiornika roztworem kwasu solnego. Po tej operacji spłukuje się zbiorniki roztworem neutralizującym, a następnie kilka razy wodą słodką aż do zlikwidowania śladów kwasów i neutralizatorów. Następnie osusza się zbiorniki i ich powierzchnię oraz pokrywa się je cienką warstwą farby przeciwkorozyjnej. Żeby uniemożliwić utlenianie powierzchni, należy do minimum skrócić czas między czyszczeniem i nałożeniem farby. Czyszczenie tą metodą jest ok. 50\% tańsze od piaskowania.

Usuwanie osadów ze zbiorników: Podczas balastowania statku w porcie do zbiorników zasysane są znaczne ilości mułu. Muł osadza się, tworząc na dnie zbiorników gęstą maź, której nie można odpompować przy osuszaniu zbiorników. Warstwa osadów powiększa się z każdą operacją. Osady te mogą powodować znaczne ubytki korozyjne konstrukcji. Przed przystapieniem do remontu statku osady te trzeba całkowicie usunąć. Najczęściej stosowaną metodą jest najprostsze, chociaż uciążliwe zbieranie osadów do wiader.

Dokładniejsze informacje dotyczące przygotowania konstrukcji do malowania można znaleźć w normach: PN ISO-8501, 8502, 8503 i 8504.

Tablica III. Wymagania dotyczące oceny powierzchni po śrutowaniu [6]

Table III. The requirements for the assessment of surface after shot peening [6]

\begin{tabular}{|l|l|l|}
\hline \multicolumn{1}{|c|}{ Oceniana cecha } & \multicolumn{1}{c|}{ Wymagania } & \multicolumn{1}{c|}{ Metoda oceny } \\
\hline Stopień czystości & Nie niżej od Sa 2,5 & Wizualnie wg PN-ISO 8501-1 \\
\hline Chropowatość powierzchni Rz & $40 \div 75 \mathrm{~mm}$ & Automatycznie uzyskiwana przy zastosowaniu granulacji ścierniwa 0,3 $\div 1,2 \mathrm{~mm}$ \\
\hline Stopień odpylenia & $\begin{array}{l}\text { Zanieczyszczeń nie więcej niż } \\
\text { na rys. 1 poz. 3, wg ISO 8502-3 }\end{array}$ & Przez naklejenie taśmy samoprzylepnej i porównanie ze wzorcem \\
\hline Obecność zatłuszczeń & Nie dopuszcza się & Brak zatłuszczenia krążka bibuły \\
\hline
\end{tabular}




\section{Konserwacja za pomocą nakładania powłok ochronnych $[4,7]$}

Idealna powłoka powinna całkowicie izolować stal od środowiska oraz mieć odpowiednio wysoką odporność na jego niszczące oddziaływanie. Ponadto powinna odznaczać się odpornością na uszkodzenia mechaniczne i łatwością nakładania.

Wybór powłoki musi być uzależniony od warunków pracy konstrukcji i powłoki. Ochronne działanie powłok może polegać na:

- działaniu zaporowym, tj. izolacji chronionego metalu od środowiska korozyjnego,

- inhibicji procesów korozyjnych w porach powłoki oraz działaniu zaporowym,

- ochronie elektrochemicznej w porach powłoki przy równoczesnym działaniu zaporowym.

W celu uzyskania pożądanych efektów ochronnych należy w każdym wypadku:

- dobrać odpowiedni rodzaj powłoki i odpowiednią technologię wykonania,

- zapewnić właściwy stopień przygotowania powierzchni,

- zapewnić wysoką jakość wykonawstwa - dotrzymanie parametrów technologicznych,

- przeprowadzić kontrolę gotowej powłoki.

Przy doborze powłok malarskich można posłużyć się szeregiem przepisów, norm, poradników i wytycznych, a także katalogami producentów farb, m.in.: Sigma Coatings B.V.; Jotun; Kansai; Hempel.

Ogólne zasady doboru powłoki to uwzględnienie: agresywności środowiska, stanu powierzchni malowanej, wymaganego okresu trwałości powłoki ( $2 \div 5$ lat

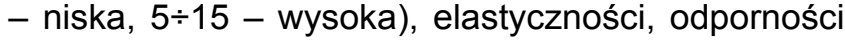
mechanicznej i chemicznej, warunków malowania, właściwości farby (czas schnięcia, wymagane podłoże i grubość warstwy) i różnych farb do różnych celów (zbiorniki balastowe i wody pitnej, pokłady).

\section{Farby malarskie}

Farby można dzielić wg funkcji, jakie spełniają w zestawie farb malarskich, na:

1) farby gruntowe - przeznaczone do nakładania bezpośredniego na powierzchnię przygotowaną do malowania i bez odpowiedniej odporności na oddziaływanie środowiska. Powinny mieć dobrą przyczepność do podłoża i stanowić dobry grunt pod następne warstwy. Opracowano farby gruntujące na powierzchnie z niecałkowicie usuniętą rdzą:

- stabilizujące - przekształcają rdzę na stabilniejszy tlenek żelaza,

- przetwarzające - reagują z rdzą, tworząc stabilniejsze kompleksy,

- penetrujące rdzę - penetrują i zabezpieczają przed dalszym rozprzestrzenianiem,

- barierowe - odcinają podłoże od czynników korozyjnych;
2) farby podkładowe - tworzące międzywarstwę, której zadaniem jest wyrównanie powierzchni i ujednolicenie barwy podłoża. Powłoka ta jest bardziej elastyczna i odporna na działanie środowiska od powłoki gruntowej. Zatrzymuje przy tym substancje agresywne, mogące przenikać przez powłokę nawierzchniową;

3) farby nawierzchniowe - tworzące powłokę zewnętrzną, zabezpieczającą poprzednie warstwy
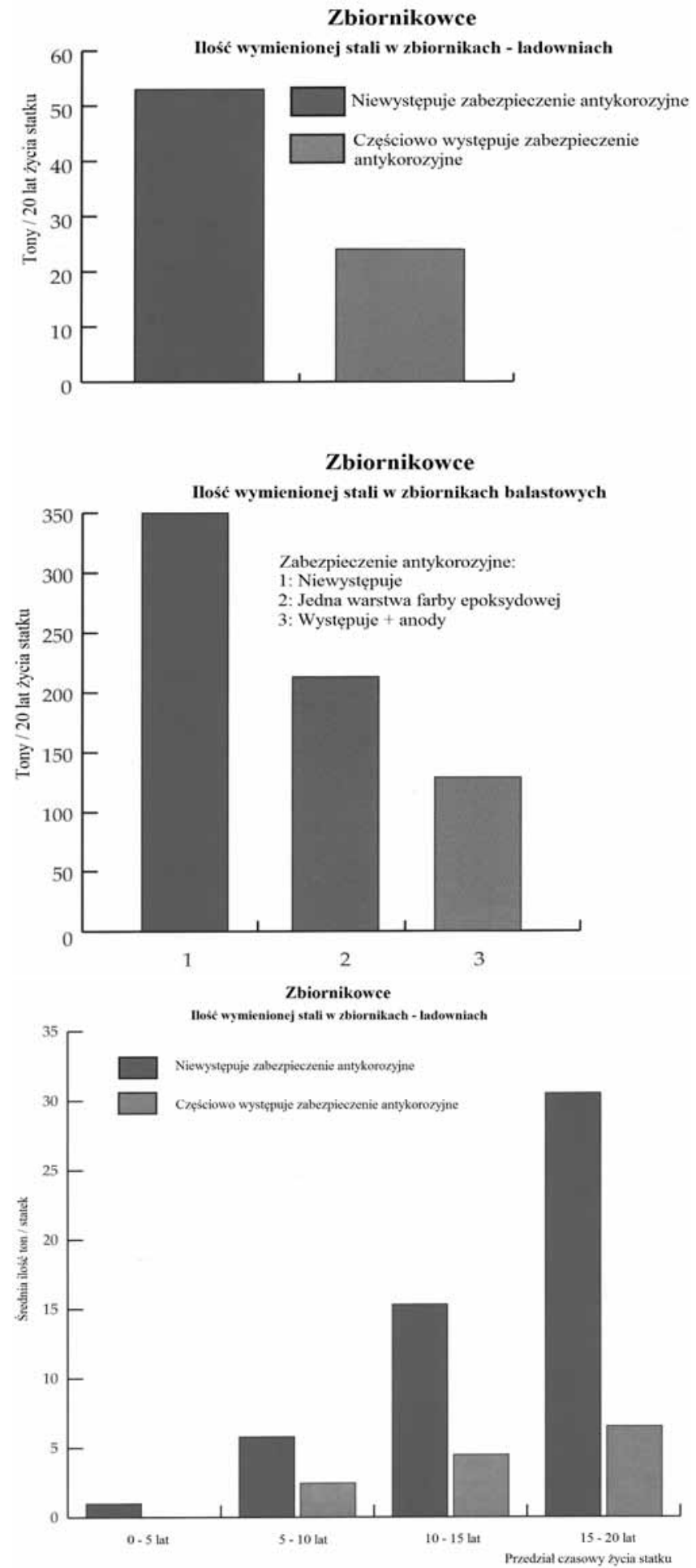

Rys. 12. llość wymienionej stali w zależności od zabezpieczenia antykorozyjnego [5]

Fig. 12. Number of replacement steel depending on corrosion protection [5] 
malarskie przed wpływami agresywnego środowiska i dające odpowiedni kolor. Właściwości farby muszą odpowiadać warunkom eksploatacji zabezpieczanego obiektu, a więc:

- farby pokładowe - muszą mieć dużą odporność na ścieranie,

- farby zbiornikowe - muszą być odporne na działanie olejów mineralnych i wody morskiej,

- farby przeciwporostowe - mają chronić podwodną część kadłuba przed korozją i porastaniem.

\section{Powłoki metaliczne}

Powłoki te powinny tworzyć na chronionej powierzchni stali warstwę ciągłą, dobrze przyczepną do podłoża i odporną na uszkodzenia mechaniczne. Powinny mieć znacznie większą odporność na korozję w środowisku morskim niż chroniona stal. W wypadku ochrony elementów konstrukcji zanurzonych stale lub okresowo w wodzie morskiej wskazane jest stosowanie powłok z metali, które w tym środowisku mają po-

\section{Podsumowanie}

Łatwo zaobserwować, ile ton stali wymienia się na statkach bez zabezpieczeń antykorozyjnych, a ile na zabezpieczonych jednostkach tego samego typu w zależności od wieku statku (rys. 12). Odpowiednie czyszczenie i właściwa konserwacja konstrukcji statku powinna być priorytetem dla armatora. Jest to lepsze i tańsze rozwiązanie niż częste wymiany poszycia i elementów, a co za tym idzie - częstsze przestoje i dokowania statku. Pociąga to za sobą straty finansowe, a także niebezpieczeństwo utraty zatrudnienia statku ze względu na jego zły stan. Warto pamiętać, że długoletnie zaniedbania konserwacji nie raz kończyły się tragicznymi katastrofami ekologicznymi (np. nadmierne przekorodowanie konstrukcji zbiornikowca przewożącego produkty ropopochodne). tencjał elektrochemiczny bardziej elektroujemny niż stal, tj.: powłoki cynkowe, aluminiowe i kadmowe.

Stosuje się różne metody pokrywania stali powłokami metalicznymi, np.: metodę galwanotechniczną, zanurzania do roztopionego metalu, natrysku, platerowania.

W budownictwie okrętowym ochronne powłoki metaliczne mają zastosowanie głównie do ochrony elementów wyposażenia statków, ale również do ochrony poszycia kadłubów. Do tego celu używa się najczęściej powłok cynkowych, rzadziej aluminiowych - wymagane jest oczyszczenie powierzchni do Sa 2,5.

\section{Schemat malowania}

Przed przystąpieniem do malowania należy opracować jego dokładny schemat, uwzględniający rodzaj powierzchni pokrywanej i warunki jej eksploatacji. Powinien on podawać stopień czystości powierzchni przed malowaniem, rodzaje farb, liczbę warstw, metodę nakładania farby i odstępy czasowe między nakładaniem kolejnych warstw.

\section{Literatura}

[1] Metschkow B.: Wykłady z przedmiotu „Technologia budowy kadłubów okrętowych", Szczecin 2005

[2] Strona internetowa: www.money.pl

[3] Polski Rejestr Statków, Przepisy klasyfikacji i budowy statków morskich, Cz. II, Kadłub, PRS Gdańsk 2002.

[4] Chmielowski A.: Zabezpieczenie przeciwkorozyjne konstrukcji stalowych, Andrzej Chmielowski, Wrocław 1997.

[5] Co-operative Forum: Condition evaluation and maintenance of tanker structures, Londyn 1992.

[6] Doerffer J.: Technologia remontów statków, Wydawnictwo Morskie, Gdańsk 1974.

[7] Katalog farb JOTUN: Coating Organiser, 2010.

[8] Nickel Magazine On-line: http://www.nickelmagazine.org

[9] Zdjęcia autorskie wykonane podczas pobytów w portach i stoczniach.

\section{SpawnhryIcTü \\ www.pspaw.ps.pl}

